\title{
ANALISIS PERPINDAHAN PANAS PADA KOLEKTOR PEMANAS AIR TENAGA SURYA DENGAN TURBULENCE ENHANCER
}

\author{
Nizar Ramadhan ${ }^{1}$, Sudjito Soeparman², Agung Widodo 3 \\ 1, 2, 3 Jurusan Teknik Mesin Fakultas Teknik Universitas Brawijaya \\ JI. MT Haryono No. 167, Malang (65145) - Indonesia \\ Telp./Fax: (0341) 554291 \\ E-mail: nizarrrr03@yahoo.com
}

\begin{abstract}
One of the solar energy utilization is solar water heater. To improve the performance of solar water heater, modifications were applied to dual absorber plate and flow channels to increase heat absorption. The aim of this study is to analyze the heat transfer of the collector solar water heater with additional modifications turbulence enhancer. Flowrate of water were varied to 1500 $\mathrm{ml} / \mathrm{min}, 1200 \mathrm{ml} / \mathrm{min}, 900 \mathrm{ml} / \mathrm{min}$, and $700 \mathrm{ml} / \mathrm{min}$. The result shown that the highest collector energy loss (Qloss) and useful energy (Qu) are 92.23 Watt and 653.83 Watt, respectively, in a volume flow rate of $700 \mathrm{ml} / \mathrm{min}$ and the total solar radiation of $672.78 \mathrm{~W} / \mathrm{m}^{2}$. The useful energy $(Q u)$ increase with reducing the volume flow rate of water. This is due to by reducing the volume flow rate, the heated water will expose longer to absorb the heat from absorber plate.
\end{abstract}

Keywords: Solar water heater double plate, turbulence enhancer, heat transfer, energy useful, energy losses

\section{PENDAHULUAN}

Permasalahan energi akan tetap menjadi topik yang harus dicarikan solusinya secara bersama-sama. Segala usaha untuk mendapatkan energi alternatif dilakukan untuk mengurangi ketergantungan terhadap sumber daya minyak bumi. Salah satu energi alternatif yang bisa dikedepankan adalah energi surya. Untuk meningkatkan efektifitas pemanfaatan energi surya secara langsung, dapat dikembangkan dengan menggunakan pengumpul-pengumpul panas yang biasa disebut kolektor. Salah satu pemanfaatan kolektor surya adalah kolektor surya pemanas air. Sebuah kolektor surya umumnya terdiri dari pelat penyerap yang memiliki konduktivitas termal yang baik, dimana pelat penyerap ini berhubungan dengan pipa-pipa yang mengalirkan fluida, dan sebuah atau lebih penutup tembus cahaya di bagian atas. Energi radiasi matahari yang datang ditransmisikan melalui penutup transparan dan diubah menjadi panas oleh pelat penyerap dimana bagian dasar dan sisi kolektor diberi isolasi. Panas yang diterima oleh pelat penyerap selanjutnya dikonduksikan ke pipa-pipa pembawa cairan.

Salah satu parameter yang berpengaruh pada kolektor surya pemanas air adalah absorber dari kolektor surya tersebut. Pada kolektor surya dengan saluran pipa dibutuhkan pengelasan untuk menghubungkan pipa dan pelat yang menimbulkan adanya tahanan termal yang akan menghambat perpindahan panas konveksi dari pelat absorber ke aliran dalam pipa. Untuk mengatasi permasalahan di atas, perlu dilakukan penelitian mengenai kolektor surya pemanas air tanpa menggunakan pipa sebagai media yang mengalirkan air. Ini bertujuan agar panas matahari yang diserap oleh pelat absorber langsung dapat ditransfer ke fluida yang mengalir di bawahnya.

Salah satu cara metode pasif yang umum untuk meningkatkan transfer panas yaitu menggunakan permukaan yang bergelombang sehingga menghasilkan aliran turbulen lokal dalam penukar panas. Modifikasi dari bentuk geometri permukaan pada saluran aliran fluida yang dipanaskan dapat meningkatkan nilai perpindahan panas konveksi yang terjadi.

Beberapa hasil penelitian sebelumnya menunjukkan modifikasi saluran dengan tambahan gelombang pada konstruksi solar water heater pelat penyerap ganda model gelombang akan menghasilkan luasan yang lebih besar dan tegak lurus terhadap datangnya 
radiasi matahari, sehingga jumlah panas yang diserap menjadi lebih besar dan dapat meningkatkan efisiensi solar water heater jika dibandingkan dengan pelat penyerap ganda model datar [1]. Semakin besar laju aliran akan menyebabkan waktu dari fluida kerja untuk menyerap panas lebih sedikit, sehingga berpengaruh terhadap efisiensi yang dihasilkan solar water heater. Efisiensi penyerapan panas yang diperoleh pada solar heater pelat penyerap ganda lebih tinggi dibandingkan dengan solar water heater konvensial [2]. Penggunaan turbulence promoter juga memperlihatkan hasil yang signifikan pada efisiensi yang dihasilkan kolektor. Efisiensi yang dihasilkan oleh pemanas air tanpa turbulence promoter adalah 62,34\%, sedangkan pada pemanas air dengan turbulence promoter adalah 67,5\% [3].

Selain penggunaan turbulence promoter, penyisipan sekat pada tabung saluran kolektor surya juga dilakukan pada studi eksperimental tentang friction factor dan heat transfer pada pemanas air tenaga surya yang dilengkapi dengan sekat $5 \mathrm{~cm}$. Penggunaan sekat terbukti meningkatkan kinerja pemanas air tenaga surya [4]. Penambahan gulungan kawat diaplikasikan untuk meningkatkan perpindahan panas pada solar water heater pelat datar pada laju aliran massa $0,04 \mathrm{~kg} / \mathrm{s}$, yang terbukti dapat meningkatkan tingkat perpindahan panas dan efisiensi termal [5].

Selain modifikasi pada saluran, kondisi pada tiap komponen kolektor juga mempengaruhi terhadap perpindahan panas dan efisiensi dari kolektor. Pengaruh jarak kaca ke pelat absorber berpengaruh terhadap temperatur pelat, yang menyatakan besar panas yang diterima. Penggunaan jenis kaca bening ketebalan $3 \mathrm{~mm}$ dengan jarak kaca ke pelat penyerap $20 \mathrm{~mm}$ akan menyebabkan temperatur pelat menjadi lebih tinggi [6]. Efisiensi sirip tertinggi yang dihasilkan dengan ketebalan pelat $1,2 \mathrm{~mm}$ dan jarak antar pipa penyalur cairan 73,6 $\mathrm{mm}$ [7].

Pengaruh penyerapan radiasi pada kaca penutup tunggal dan ganda pada kolektor surya terhadap koefisien perpindahan panas menghasilkan bahwa penyerapan radiasi matahari pada kaca penutup tunggal mampu meningkatkan suhu sebesar $6^{\circ} \mathrm{C}$. Dan untuk kolektor dengan kaca penutup ganda mampu meningkatkan penyerapan radiasi matahari sebesar $11^{\circ} \mathrm{C}$ [8]. Variasi sudut kemiringan kolektor sebesar $10^{\circ}, 20^{\circ}$, dan $30^{\circ}$ memperlihatkan hasil temperatur air keluar kolektor tertinggi terjadi pada sudut kemiringan kolektor $30^{\circ}$ yaitu sebesar $42,8^{\circ} \mathrm{C}$ untuk 1 kaca penutup, sedangkan untuk 2 kaca penutup temperatur sebesar $44,8{ }^{\circ} \mathrm{C}$. Efisiensi rata-rata kolektor surya satu kaca penutup $51,98 \%$, dan untuk efisiensi rata-rata solar kolektor surya dua kaca penutup 56,21\% [9].

Dari beberapa penelitian terdahulu yang pernah dilakukan maka perlu dilakukan pengembangan penelitian selanjutnya mengenai variasi lain dari kolektor surya pelat datar dengan penggunaan alur zig zag dan turbulence enhancer dengan geometri persegi panjang. Tujuan dari kolektor model ini untuk memperbesar luasan permukaan yang dapat langsung menangkap radiasi matahari serta memperpanjang lintasan air untuk memaksimalkan penyerapan panas air dari pelat penyerap. Selain itu, penambahan turbulence enhancer pada saluran fluida dapat merekayasa aliran, sehingga tercipta aliran turbulen lokal pada saat proses penyerapan panas oleh air. Dengan ini diharapkan dapat meningkatkan koefisien perpindahan panas konveksi dari absorber ke air dan efisiensi yang dihasilkan oleh kolektor surya.

Penelitian ini bertujuan untuk mengetahui pengaruh intensitas radiasi matahari terhadap energi berguna dan kerugian energi yang dihasilkan kolektor pemanas air tenaga surya dengan turbulence enhancer, serta koefisien perpindahan panas konveksi antara pelat absorber dan air, berdasarkan variasi laju aliran volume air.

\section{METODOLOGI PENELITIAN}

Penelitian ini bertujuan untuk menganalisis pengaruh geometri alur zig-zag dan turbulence enhancer persegi panjang terhadap perpindahan panas yang terjadi pada pemanas air tenaga surya. Adapun yang menjadi variabel bebas yang digunakan adalah laju aliran volume dengan variasi 700 $\mathrm{mL} / \mathrm{menit}, 900 \mathrm{ml} /$ menit, $1.000 \mathrm{ml} /$ menit dan $1.500 \mathrm{ml} / \mathrm{menit}$. Variabel terikatnya adalah temperatur lingkungan $\left(\mathrm{T}_{\mathrm{a}}\right)$, temperatur kaca penutup $\left(T_{g}\right)$, temperatur pelat absorber $\left(T_{p}\right)$, temperatur air masuk $\left(T_{\text {in }}\right)$, temperatur air keluar ( $\left.T_{\text {out }}\right)$, radiasi total matahari $\left(G_{t}\right)$, energi berguna $\left(\mathrm{Q}_{\mathrm{u}}\right)$, kerugian energi (Qloss), dan 
koefisien perpindahan kalor konveksi $\left(h_{c}\right)$ antara pelat absorber ke air.

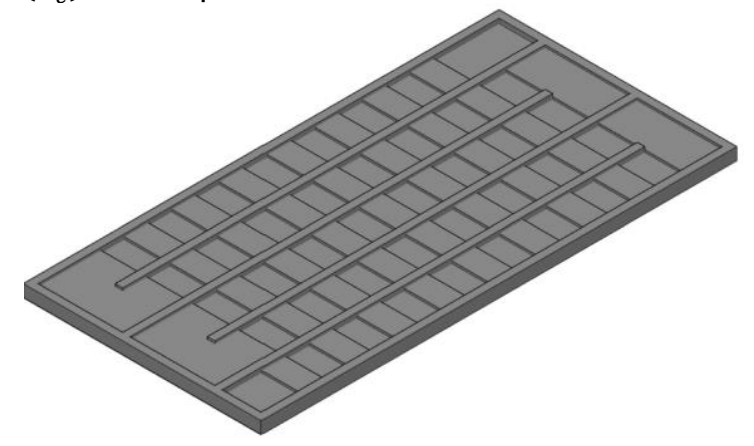

Gambar 1. Pelat polyethylene dengan turbulence enhancer

Pengujian diawali dengan meletakkan kolektor pemanas air tenaga surya di bawah radiasi matahari secara langsung, dan memposisikannya sesuai dengan arah matahari untuk daerah Malang dengan posisi $7,95^{\circ} \mathrm{LS}$ dan $112,06^{\circ} \mathrm{BT}$ untuk tanggal 27 April 2016 hingga 9 Mei 2016. Posisi matahari akan cenderung pada lintang utara, sehingga kolektor diposisikan menghadap utara-selatan.

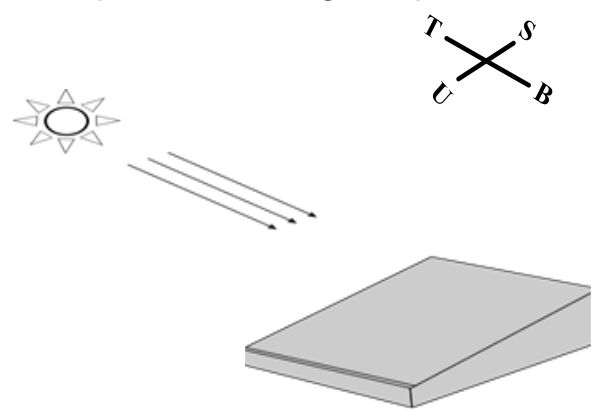

Gambar 2. Posisi peletakan kolektor pemanas air terhadap matahari

Sebelum melakukan beberapa tahapan pengambilan data, perlu dilakukan persiapan peralatan-peralatan serta memastikan alat dapat bekerja dengan baik dan aman. Selain itu perlu dilakukan kalibrasi peralatan ukur yang akan digunakan untuk menjamin ketepatan hasil pengukuran. Kemudian menyalakan komputer dan data logger yang terhubung dengan komputer untuk persiapan pengambilan data dan dilakukan running program untuk pengecekan sensor-sensor yang terhubung pada kolektor pemanas air, yang masing-masing sensor diletakkan sesuai dengan fungsinya sesuai instalasi penelitian pada Gambar 3.

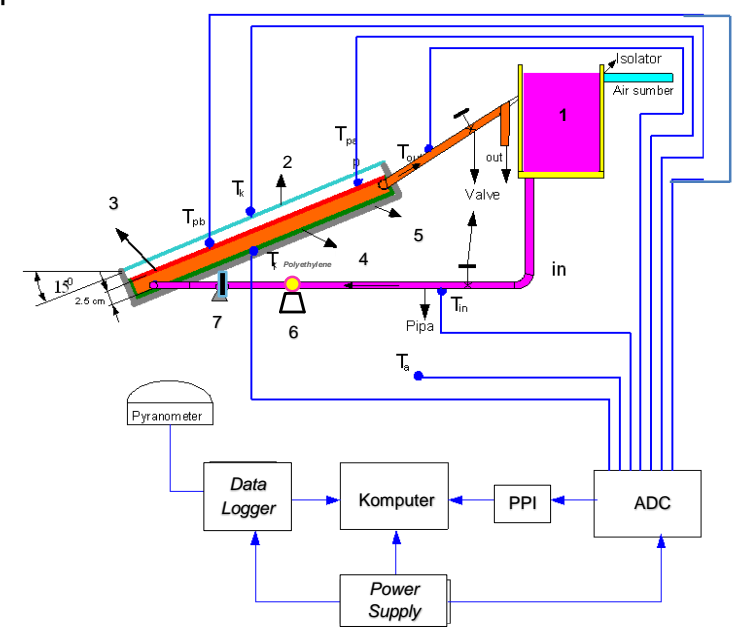

Gambar 3. Instalasi penelitian

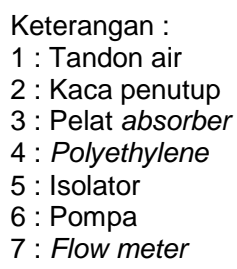

Pengambilan data dilakukan dalam kondisi cuaca cerah, dimulai pada pukul 08.00 - 15.00 WIB dengan interval waktu setiap 5 menit sampai waktu pengambilan data terpenuhi untuk setiap harinya. Prosedur pengambilan data diawali dengan melakukan pengisian air pada bak penampungan, yang dilanjutkan dengan meyalakan pompa air dan membuka keran air dari bak penampungan agar air dapat mengalir menuju kolektor untuk dipanaskan oleh kolektor pemanas air tenaga surya. Variasi laju aliran volume air yang masuk ke saluran kolektor $(1500 \mathrm{ml} / \mathrm{menit}, 1200$ $\mathrm{ml} /$ menit, $900 \mathrm{ml} /$ menit, dan $700 \mathrm{ml} /$ menit) diatur dengan menggunakan flowmeter. Untuk pengambilan data dilakukan sebanyak dua hari berdasarkan setiap variasi. Setelah waktu pengambilan data dalam 1 hari selesai dilakukan, selanjutnya data disimpan untuk diolah pada proses analisa data.

\section{HASIL DAN PEMBAHASAN}


A. Intensitas Radiasi Total Matahari Terhadap Waktu Penelitian

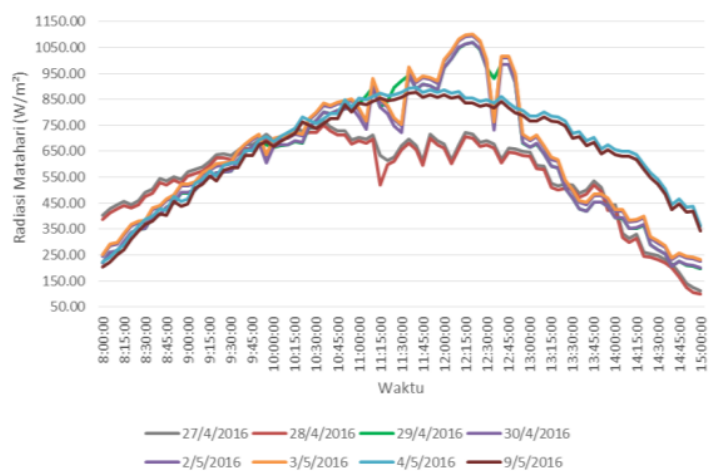

Gambar 4. Hubungan intensitas radiasi total matahari terhadap waktu penelitian

Radiasi total matahari yang diterima dari pukul 08.00 WIB, akan mengalami kenaikan dan mencapai radiasi puncaknya antara pukul 11.00 WIB sampai dengan pukul 13.00 WIB. Selepas dari jam tersebut, secara perlahan radiasi matahari yang diterima akan mengalami penurunan hingga menjelang sore hari. Nilai rata-rata radiasi total matahari yang diterima oleh pyranometer bervariasi, yaitu $555 \mathrm{~W} / \mathrm{m}^{2}-$ $617 \mathrm{~W} / \mathrm{m}^{2}$ pada pagi hari (jam $08.00 \mathrm{WIB}$ $10.55 \mathrm{WIB}), 650 \mathrm{~W} / \mathrm{m}^{2}-920 \mathrm{~W} / \mathrm{m}^{2}$ pada siang hari (jam 11.00 WIB - 13.00 WIB), dan 355 $\mathrm{W} / \mathrm{m}^{2}-630 \mathrm{~W} / \mathrm{m}^{2}$ pada sore hari (jam 13.05 WIB - 15.00 WIB.

Salah satu faktor yang mempengaruhi besar kecilnya radiasi matahari yang diterima oleh pyranometer dan kolektor surya, yaitu sudut datang sinar matahari. Semakin tegak sinar matahari yang datang, semakin tinggi radiasi total matahari yang diterima. Seperti yang terlihat pada Gambar 4, dimana rata-rata radiasi total matahari pada waktu jam puncak radiasi (siang hari) memiliki nilai yang lebih tinggi daripada pada waktu pagi dan sore hari. Ini disebabkan posisi matahari terhadap kolektor yang lebih miring pada pagi hari dan sore hari, sehingga radiasi total matahari yang diterima lebih rendah bila dibandingkan pada saat siang hari dimana posisi matahari tegak lurus dengan pyranometer dan kolektor.

Kemudian faktor lain yang juga mempengaruhi intensitas radiasi matahari adalah kondisi atmosfir, seperti awan, debu, uap air, dan gas-gas di atmosfer. Pada Gambar 4 terlihat terjadi penurunan radiasi total matahari pada saat lepas dari kondisi puncak radiasi pada siang hari. Hal ini dikarenakan perubahan kondisi cuaca pada menjelang sore hari, yang cenderung mendung dan berawan sehingga radiasi matahari yang diterima oleh pyranometer dan kolektor menjadi terhalang oleh gumpalan awan pada saat menjelang sore hari.

\section{B. Hubungan Rata-Rata Temperatur dan Intensitas Radiasi Matahari Total Pada Pengujian Laju Aliran Volume}

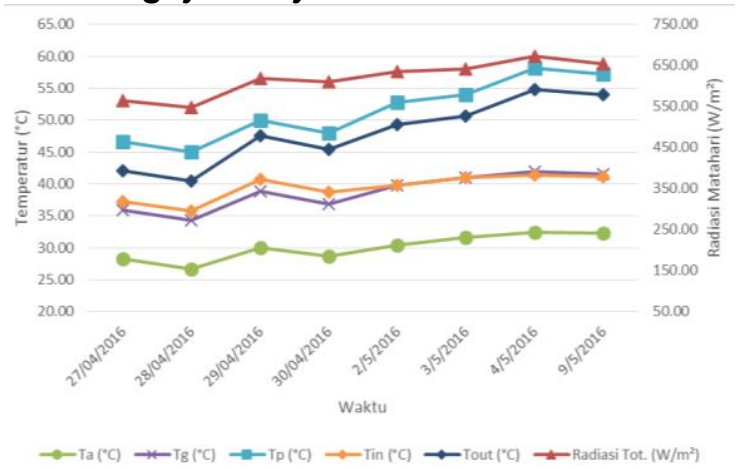

Gambar 5. Hubungan rata-rata temperatur dan intensitas radiasi matahari total pada pengujian laju aliran volume

Dari Gambar 5 terlihat intensitas radiasi matahari total rata-rata mempunyai pola yang sama dengan temperatur rata-rata pengamatan (temperatur lingkungan, temperatur kaca penutup, temperatur pelat penyerap, temperatur air masuk dan temperatur air keluar). Ini menandakan bahwa jumlah energi yang diserap oleh kolektor pemanas air tenaga surya akan sesuai dengan sumber energinya, yaitu energi matahari. Kondisi maksimal ratarata temperatur lingkungan dari hasil pengamatan sebesar $32,41^{\circ} \mathrm{C}$ pada radiasi total matahari $672,78 \mathrm{~W} / \mathrm{m}^{2}$. Sedangkan kondisi minimum rata-rata temperatur lingkungan pada pengamatan ini sebesar $26,66^{\circ} \mathrm{C}$ pada radiasi total matahari $547,03 \mathrm{~W} / \mathrm{m}^{2}$. Selain pengaruh dari radiasi matahari, temperatur lingkungan juga dipengaruhi oleh kelembaban (humidity) lingkungan sekitar kolektor. Apabila keadaan lingkungan cenderung lembab dan basah, maka temperatur lingkungan menjadi rendah, dan apabila keadaan lingkungan semakin kering, maka temperatur lingkungan menjadi tinggi.

Pada Gambar 5, rata-rata temperatur kaca penutup dan temperatur pelat absorber 
maksimum masing-masing sebesar $41,96^{\circ} \mathrm{C}$ dan $58,18^{\circ} \mathrm{C}$. Sedangkan rata-rata temperatur kaca penutup dan temperatur pelat absorber minimum masing-masing sebesar $34,32^{\circ} \mathrm{C}$ dan $44,99{ }^{\circ} \mathrm{C}$. Untuk temperatur kaca penutup, faktor yang sangat berpengaruh adalah temperatur lingkungan dan radiasi matahari. Apabila temperatur lingkungan di sekitar kolektor dan terpaan radiasi matahari ke kaca penutup kolektor semakin besar, maka temperatur kaca penutup juga mengalami kenaikan. Sedangkan keadaan temperatur pelat absorber sangat bergantung dengan kondisi pada kaca penutup kolektor. Kemampuan transmisivitas yang baik dari kaca penutup adalah salah satu faktor penting untuk meningkatkan temperatur pada pelat absorber, dimana transmisivitas merupakan kemampuan suatu material dalam meneruskan energi panas dari radiasi matahari.

Tren kenaikan yang sama juga terlihat antara temperatur air input dan temperatur air output. Hal yang paling mendasari semakin besarnya temperatur air output yang dihasilkan tentu saja tergantung oleh besar atau kecilnya energi panas yang disuplai ke aliran air dalam saluran kolektor surya, terutama panas yang disuplai oleh pelat absorber yang bersinggungan langsung dengan aliran air yang ada di bawahnya.

\section{Hubungan Rata-Rata Kerugian Energi $\left(Q_{\text {loss }}\right)$ dan Intensitas Radiasi Matahari Total Pada Pengujian Laju Aliran Volume}

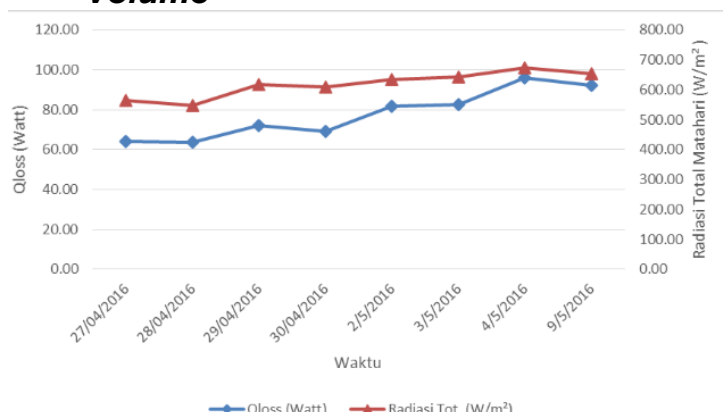

Gambar 6. Hubungan intensitas radiasi total matahari terhadap kerugian energi pada pengujian laju aliran volume

Pada Gambar 6, terjadi hubungan yang saling berbanding lurus antara intensitas radiasi total matahari terhadap kerugian energi kolektor. Tren peningkatan dari radiasi matahari yang diamati, diikuti juga dengan meningkatnya kerugian energi kolektor. Dari pengamatan pada tanggal 4 Mei 2016 (pengujian laju aliran volume $700 \mathrm{ml} / \mathrm{menit}$ ) didapatkan rata-rata kerugian energi kolektor tertinggi sebesar 92,23 Watt pada radiasi total matahari $672,78 \mathrm{~W} / \mathrm{m}^{2}$. Sedangkan dari pengamatan pada tanggal 28 April 2016 (pengujian laju aliran volume 1500 $\mathrm{ml} /$ menit) didapatkan rata-rata kerugian energi kolektor paling rendah sebesar 63,54 Watt pada radiasi total matahari $547,03 \mathrm{~W} / \mathrm{m}^{2}$.

Kerugian energi yang terjadi dalam kolektor pemanas air tenaga surya tidak terlepas dari kerugian kalor yang terjadi pada bagian atas kolektor $\left(U_{t}\right)$, kerugian kalor pada bagian samping kolektor $\left(U_{e}\right)$, dan kerugian kalor pada bagian bawah kolektor $\left(U_{e}\right)$. Namun, di antara ketiga hal tersebut, untuk kerugian kalor samping dan bawah kolektor pada kebanyakan kolektor yang mempunyai sistem isolasi panas yang baik, kerugian kalor pada bagian ini dianggap kecil. Untuk kerugian kalor pada bagian atas kolektor, keterlibatan setiap komponen dari kolektor (temperatur kaca penutup dan temperatur pelat absorber) dan faktor dari lingkungan sekitar kolektor (temperatur lingkungan, kecepatan angin, dan intensitas radiasi matahari) menjadi penyebab besar atau kecilnya energi yang hilang dari kolektor.

Proses perpindahan panas radiasi dan konveksi yang melibatkan kaca penutup dengan lingkungan merupakan faktor pertama yang berpengaruh terhadap kerugian energi kolektor. Kondisi terpaan radiasi matahari yang semakin besar maka akan diikuti juga dengan meningkatnya temperatur lingkungan dan kaca penutup. Rata-rata kerugian energi kolektor tertinggi sebesar 92,23 Watt pada radiasi total matahari $672,78 \mathrm{~W} / \mathrm{m}^{2}$. Dalam kasus ini, ratarata temperatur lingkungan dan kaca penutup juga mencapai maksimum, dimana nilainya masing-masing sebesar $32,41^{\circ} \mathrm{C}$ dan $41,96^{\circ} \mathrm{C}$, sehingga menghasilkan rata-rata koefisien perpindahan kalor radiasi antara kaca penutup dan lingkungan maksimum $6,23 \mathrm{~W} / \mathrm{m}^{2} \mathrm{~K}$. Sedangkan, pada perpindahan panas konveksi pada bagian atas kolektor melibatkan kecepatan angin yang berhembus di atas kaca penutup kolektor. Karena hubungan yang berbanding lurus, maka semakin besar kecepatan angin yang terjadi, maka semakin 
besar pula koefisien perpindahan kalor konveksi dari kaca penutup dan lingkungan.

Faktor kedua, proses perpindahan kalor radiasi dan konveksi yang melibatkan pelat absorber dengan kaca penutup. Untuk koefisien perpindahan kalor radiasi yang melibatkan pelat absorber dengan kaca penutup, parameter yang paling mempengaruhi adalah kondisi temperatur pelat absorber dan kaca penutup. Peningkatan temperatur yang terjadi pada pelat absorber dan kaca penutup akan mengakibatkan peningkatan kerugian kalor pada bagian atas kolektor, dan begitu pula sebaliknya. Intensitas radiasi matahari sebagai sumber energi panas yang diserap oleh kaca penutup dan pelat absorber menjadi penentu besar atau kecilnya temperatur dari kedua komponen tersebut. Pada saat intensitas radiasi matahari mencapai puncaknya (jam 11.00 WIB-13.00 WIB), temperatur kaca penutup dan pelat absorber akan mencapai nilai maksimumnya. Nilai temperatur rata-rata maksimum kaca penutup dan pelat absorber juga mencapai maksimum sebesar $41,96^{\circ} \mathrm{C}$ dan $58,18^{\circ} \mathrm{C}$, pada kondisi rata-rata intensitas radiasi total matahari $672,78 \mathrm{~W} / \mathrm{m}^{2}$, sehingga menghasilkan rata-rata koefisien perpindahan kalor radiasi antara kaca penutup dan pelat absorber maksimum 6,26 W/m² K. Dalam proses perpindahan kalor konveksi yang melibatkan pelat absorber dengan kaca penutup melibatkan fluida udara yang mengisi di antara pelat absorber dan kaca penutup, ditentukan oleh nilai Rayleigh $(R a)$ dan nilai Nusselt $(\mathrm{Nu})$. Selain nilai Nusselt, hal lain yang mempengaruhi yaitu konduktivitas termal dari udara. Semakin besar nilai konduktivitas termal udara, maka semakin besar koefisien kerugian kalor konveksi pelat absorber dan kaca penutup. Koefisien kerugian kalor konveksi pelat absorber dan kaca penutup maksimum adalah $3,02 \mathrm{~W} / \mathrm{m}^{2} \mathrm{~K}$, pada kondisi rata-rata intensitas radiasi total matahari $672,78 \mathrm{~W} / \mathrm{m}^{2}$.

\section{Hubungan Rata-Rata Energi Berguna $\left(Q_{u}\right)$ dan Intensitas Radiasi Matahari Total Pada Pengujian Laju Aliran Volume}

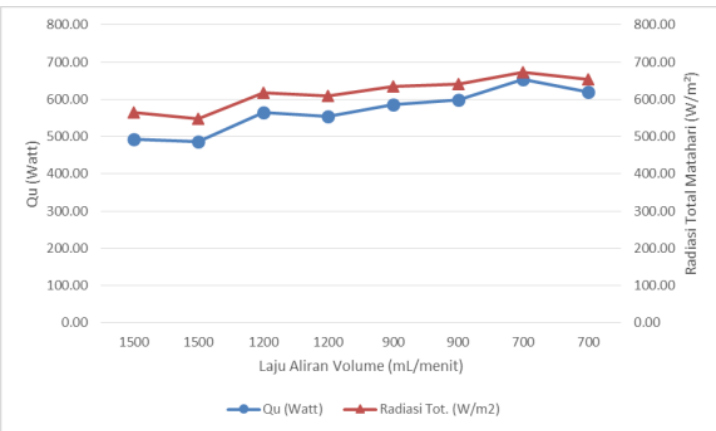

Gambar 7. Hubungan intensitas radiasi total matahari terhadap energi berguna pada pengujian laju aliran volume

Pada Gambar 7, dapat dilihat hubungan antara energi yang diserap oleh air $\left(Q_{u}\right)$ terhadap intensitas radiasi total matahari. Dari pengamatan pengujian laju aliran volume 700 $\mathrm{mL} / \mathrm{menit}$ didapatkan rata-rata energi berguna tertinggi sebesar 653,83 Watt pada radiasi total matahari $672,78 \mathrm{~W} / \mathrm{m}^{2}$. Kemudian pada pengujian laju aliran volume $900 \mathrm{~mL} /$ menit didapatkan rata-rata energi berguna tertinggi sebesar 598,26 Watt pada radiasi total matahari $641,99 \mathrm{~W} / \mathrm{m}^{2}$. Pada pengujian laju aliran volume $1200 \mathrm{~mL} / \mathrm{menit}$ didapatkan ratarata energi berguna tertinggi sebesar 565,79 Watt pada radiasi total matahari $618,73 \mathrm{~W} / \mathrm{m}^{2}$. Sedangkan pengujian laju aliran volume 1500 $\mathrm{mL} /$ menit didapatkan rata-rata energi berguna tertinggi sebesar 491,72 Watt pada radiasi total matahari 563,73 W/m².

Salah satu faktor yang mempengaruhi energi berguna yang mampu diserap oleh air dari kolektor surya adalah kondisi dari intensitas radiasi matahari pada setiap pengujian laju aliran volume. Pada pengujian laju aliran volume $700 \mathrm{~mL} /$ menit didapatkan rata-rata energi berguna sebesar 653,83 Watt pada radiasi total matahari yang besar pula, yaitu $672,78 \mathrm{~W} / \mathrm{m}^{2}$. Kemudian di saat pengujian laju aliran volume $1500 \mathrm{~mL} /$ menit didapatkan rata-rata energi berguna sebesar 491,72 Watt pada radiasi total matahari $563,73 \mathrm{~W} / \mathrm{m}^{2}$. Ini membuktikan intensitas radiasi matahari yang diserap oleh kolektor surya berpengaruh terhadap temperatur air keluar yang dihasilkan kolektor. Karena semakin besar intensitas radiasi matahari yang diserap oleh kolektor surya menunjukkan semakin besar energi yang diterima oleh pelat penyerap yang digunakan 
untuk memanaskan air yang mengalir di dalam kolektor.

Selain faktor di atas, kondisi yang mempengaruhi energi berguna yang mampu diserap oleh air adalah variasi laju aliran volume air. Semakin kecil laju aliran volume air, maka energi berguna yang mampu diserap oleh kolektor akan semakin tinggi. Ini dikarenakan pada saat laju aliran volume kecil, air yang dipanaskan akan memiliki kesempatan yang lebih lama untuk menyerap dan memanfaatkan panas yang ditransfer dari pelat absorber, sehingga meningkatkan temperatur output air saat keluar dari kolektor. Energi berguna paling tinggi yang disuplai ke air adalah pada saat pengujian laju aliran volume $700 \mathrm{ml} /$ menit dengan rata-rata energi berguna sebesar 653,83 Watt. Sedangkan, pada saat pengujian laju aliran volume $900 \mathrm{~mL} /$ menit, $1200 \mathrm{ml} /$ menit, dan $1500 \mathrm{ml} /$ menit terjadi penurunan energi berguna yang disuplai ke air, hingga pada saat pengujian laju aliran volume $1500 \mathrm{ml} /$ menit didapatkan rata-rata energi berguna paling rendah sebesar 491,72 Watt.

\section{E. Hubungan Rata-Rata Energi Berguna} $\left(Q_{u}\right)$ dan Intensitas Radiasi Matahari Total Pada Pengujian Laju Aliran Volume

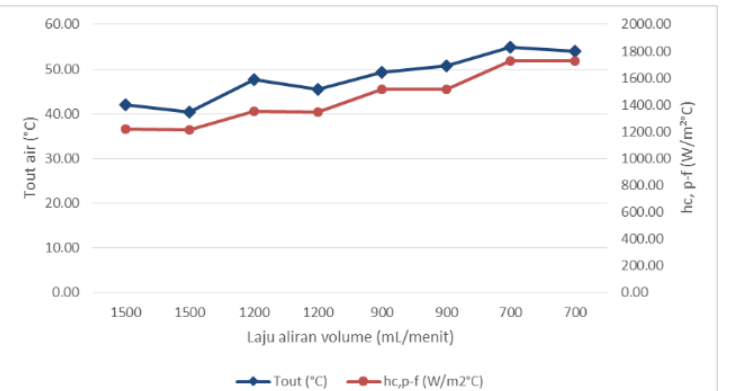

Gambar 8 Hubungan temperatur output air dengan koefisien konveksi pelat-air pada pengujian laju aliran volume

Pada Gambar 8, dapat dilihat hubungan antara koefisien perpindahan kalor konveksi antara pelat absorber dan air $\left(h_{c, p-f}\right)$ terhadap temperatur output air $\left(T_{\text {out }}\right)$ dari kolektor. Dari pengamatan pengujian laju aliran volume 700 $\mathrm{ml} /$ menit didapatkan rata-rata $h_{c, p-f}$ tertinggi sebesar $1729,50 \mathrm{~W} / \mathrm{m}^{2 \circ} \mathrm{C}$, yang menghasilkan $T_{\text {out }}$ sebesar $54,87^{\circ} \mathrm{C}$. Sedangkan pengujian laju aliran volume $1500 \mathrm{ml} / \mathrm{menit}$ didapatkan rata-rata $h_{c, p-f}$ yang paling kecil di antara semua variasi laju aliran volume, yaitu sebesar $1212,74 \mathrm{~W} / \mathrm{m}^{2 \circ} \mathrm{C}$, yang menghasilkan $T_{\text {out }}$ sebesar $40,44^{\circ} \mathrm{C}$.

Ini menandakan bahwa koefisien perpindahan kalor konveksi antara pelat absorber dan air $\left(h_{c, p-f}\right)$ sangat berpengaruh terhadap temperatur output air $\left(T_{\text {out }}\right.$ ) yang dihasilkan oleh kolektor. Nilai $h_{c, p-f}$ yang merupakan proses perpindahan kalor konveksi yang melibatkan pelat absorber dan air yang dipanaskan, memberi pengaruh terhadap temperatur output yang akan keluar dari kolektor. Nilai $h_{c, p-f}$ yang semakin tinggi akan diikuti pula dengan kenaikan dari nilai $T_{\text {out }}$ air.

Faktor yang menyebabkan meningkatnya $h_{c, p-f}$ salah satunya disebabkan oleh variasi laju aliran volume air. Semakin kecil laju aliran volume air, maka nilai $h_{c, p-f}$ yang terjadi akan semakin tinggi. Sama halnya dengan energi berguna, pada proses perpindahan kalor konveksi yang melibatkan pelat absorber dan air yang dipanaskan dengan laju aliran volume yang lebih kecil, air yang dipanaskan akan memiliki kesempatan yang lebih lama untuk menyerap kalor yang ditransfer dari pelat absorber, sehingga meningkatkan $T_{\text {out }}$ air saat keluar dari kolektor. Seperti pada pada Gambar 8 , nilai $h_{c, p-f}$ paling tinggi yang terjadi adalah pada saat pengujian laju aliran volume 700 $\mathrm{ml} /$ menit dengan rata-rata nilai $h_{c, p-f}$ sebesar $1729,50 \mathrm{~W} / \mathrm{m}^{2 \circ} \mathrm{C}$. Sedangkan, pada saat pengujian laju aliran volume $900 \mathrm{ml} /$ menit, 1200 $\mathrm{ml} / \mathrm{menit}$, dan $1500 \mathrm{ml} /$ menit terjadi penurunan energi berguna yang disuplai ke air, hingga pada saat pengujian laju aliran volume 1500 $\mathrm{ml} /$ menit didapatkan rata-rata nilai $h_{c, p-f}$ paling rendah sebesar $1212,74 \mathrm{~W} / \mathrm{m}^{2 \circ} \mathrm{C}$.

Selain faktor di atas, faktor yang dapat mempengaruhi nilai $h_{c, p-f}$ juga dipengaruhi oleh radius hidrolik $\left(R_{h}\right)$, nilai Nusselt $(\mathrm{Nu})$, dan konduktivitas termal air $(k)$. Laju aliran volume yang bervariasi $700 \mathrm{ml} /$ menit, $900 \mathrm{ml} /$ menit, $1200 \mathrm{ml} /$ menit, dan $1500 \mathrm{ml} /$ menit menyebabkan ketinggian aliran dalam saluran mengalami perbedaan pada setiap variasi laju aliran volume. Seperti pada laju aliran volume $700 \mathrm{ml} / \mathrm{menit}$, ketinggian aliran adalah 0,0014 $\mathrm{m}$, dibandingkan dengan laju aliran volume $1500 \mathrm{ml} /$ menit dengan ketinggian aliran yang lebih besar yaitu $0,002 \mathrm{~m}$. Perbedaan ketinggian aliran tersebut menyebabkan nilai 
radius hidrolik $\left(R_{h}\right)$ menjadi semakin besar pada setiap kenaikan laju aliran volume, yang juga diikuti dengan meningkatnya kecepatan rata-rata aliran $\left(V_{m}\right)$ dalam saluran. Tetapi pada sisi lain, semakin kecil kecepatan rata-rata aliran, justru akan mengakibatkan $T_{\text {out }}$ yang dihasilkan menjadi lebih besar.

\section{KESIMPULAN}

Berdasarkan penelitian yang telah dilakukan didapatkan kesimpulan sebagai berikut:

1. Peningkatan intensitas radiasi matahari akan diikuti dengan meningkatnya energi berguna $\left(Q_{u}\right)$ dan kerugian energi $\left(Q_{\text {loss }}\right)$ yang terjadi. Kerugian energi $\left(Q_{\text {loss }}\right)$ kolektor tertinggi didapatkan sebesar 92,23 Watt, dan energi berguna $\left(Q_{u}\right)$ tertinggi sebesar 653,83 Watt pada pengujian laju aliran volume $700 \mathrm{ml} / \mathrm{menit}$ dengan radiasi total matahari $672,78 \mathrm{~W} / \mathrm{m}^{2}$.

2. Koefisien perpindahan panas konveksi $\left(h_{c, p-f}\right)$ tertinggi sebesar $1729,50 \mathrm{~W} / \mathrm{m}^{2 \circ} \mathrm{C}$ pada pengujian laju aliran volume 700 $\mathrm{ml} /$ menit, dengan radiasi total matahari $672,78 \mathrm{~W} / \mathrm{m}^{2}$.

3. Semakin kecil laju aliran volume air,semakin besar pula nilai energi berguna $\left(Q_{u}\right)$ dan koefisien perpindahan panas konveksi $\left(h_{c, p-f}\right)$. Ini dikarenakan pada saat laju aliran volume yang kecil, air yang dipanaskan akan memiliki kesempatan yang lebih lama untuk menyerap panas yang disuplai dari pelat absorber.

\section{DAFTAR PUSTAKA}

[1] Farid, A. \& Ismail, N. R. 2011. Pengaruh Pelat Penyerap Ganda Model Gelombang Terhadap Kinerja Solar Water Heater Sederhana. Widya Teknika. 19 (1): 12-15.
Tenaga Matahari Pelat Ganda. Tugas Akhir. Tidak dipublikasikan. Malang: Universitas Brawijaya.

[4] Nayak, U. K., Roy, S. C., Paswan, M. K. \& Gupta, A. K. 2015. Heat Transfer and Flow Friction Characteristics of Solar Water Heater with Inserted Baffel Inside Tube. International Journal of Engineering Research \& Science (IJOER). 1 (4): 33-38.

[5] Garcia, A., Martin, R. H. \& Garcia, J. P. 2013. Experimental Study of Heat Transfer Enhancement in a Flat-Plate Solar Water Collector with Wire-Coil Inserts. Applied Thermal Engineering. 61: 461-468.

[6] Handoyo, Ekadewi Anggraini. 2001. Pengaruh Jarak Kaca Ke Plat Terhadap Panas Yang Diterima Suatu Kolektor Surya Plat Datar. JURNAL TEKNIK MESIN. 3 (2): 52-56.

[7] Kristanto, P. \& San, Y. K. 2001. Pengaruh Tebal Plat Dan Jarak Antar Pipa Terhadap Performansi Kolektor Surya Plat Datar. JURNAL TEKNIK MESIN. 3 (2): 47-51.

[8] Akhtar, N. \& Mullick, S. C. 2011. Effect of Absorption of Solar Radiation in GlassCover(s) on Heat Transfer Coefficients in Upward Heat Flow in Single and Double Glazed Flat-Plate Collectors. International Journal of Heat and Mass Transfer. 55: 125-132.

[9] Setyadi, U. D. \& Dwiyantoro, B. A. 2015. Pengaruh Sudut Kemiringan Kolektor Surya Pelat Datar terhadap Efisiensi Termal Dengan Penambahan Eksternal Annular Fin Pada Pipa. JURNAL TEKNIK ITS. 4 (1): 31-36.

[2] Mustafa \& Ismail, N. R. 2009. Pengaruh Laju Aliran Air Menggunakan Pelat Penyerap Ganda Dan Konvensional Terhadap Kinerja Solar Water Heater. PROTON. 1 (1): 23-27.

[3] Wiraradi, R. 2016. Pengaruh Turbulence Promoter Terhadap Efisiensi Pemanas Air 